\title{
Going with the flow: methotrexate, adenosine, and blood flow
}

\section{B N Cronstein}

\section{Methotrexate treatment modulates adenosine metabolism in patients with rheumatoid arthritis}

S ince its reintroduction for the treatment of rheumatoid arthritis (RA) in the 1980s, ${ }^{12}$ low dose methotrexate has become the favoured second line treatment for patients with RA and other forms of inflammatory arthritis. It is safe and effective; indeed, it is nearly as effective as the biological agents that seem to have transformed the treatment of RA, and the effects of biological agents combined with methotrexate are clearly better than either alone. ${ }^{3-7}$ Low dose methotrexate was introduced into the therapeutic armamentarium for RA on the basis of its ability to inhibit cellular proliferation, although the doses required for the antiproliferative effect in patients with cancer are considerably higher than those commonly used to treat RA ( $1-5 \mathrm{~g}$ in a bolus for cancer $v$ 10-25 mg/week for RA). Thus, the mechanism by which methotrexate suppresses inflammation has been an area of some interest.

\section{MECHANISMS OF ACTION}

Several mechanisms of action have been proposed to explain the anti-inflammatory effects of methotrexate. Inhibition of purine and pyrimidine synthesis, suppression of transmethylation reactions and accumulation of polyamines leading to suppression of $\mathrm{T}$ cell function, ${ }^{9-11}$ and promotion of adenosine release with adenosine mediated suppression of inflammation. ${ }^{12-15}$ The use of folic or folinic acid supplementation to prevent the toxicity of methotrexate without reversing its anti-inflammatory effects is not consistent with the notion that inhibition of purine/pyrimidine metabolism is responsible for the antiinflammatory effects of the drug. ${ }^{8}{ }^{16-25}$ The absence of a suppressive effect on RA activity of an agent that directly inhibits transmethylation reactions renders this hypothesis untenable. ${ }^{15} 26$ The third hypothesis, that methotrexate treatment increases adenosine release and adenosine mediates the antiinflammatory effects of methotrexate still enjoys experimental support in in vitro and animal studies (recently reviewed ${ }^{15}$ ).
Strong evidence supporting the hypothesis that adenosine mediates the anti-inflammatory effects of methotrexate has been developed in patients as well. Thus, caffeine (contained in coffee), an adenosine receptor antagonist, appears partially to block the effects of methotrexate in patients with RA. $^{27} 28$ One of the earliest signs of a response to methotrexate in the synovium is diminished expression of the orphan receptor NURRl, a phenomenon shown to be mediated by methotrexateinduced adenosine release. ${ }^{29}$ For technical reasons (adenosine has a half life in blood of about 2 seconds $^{30}$ ), it has been difficult to demonstrate that methotrexate treatment for inflammatory arthritis increases adenosine in blood or other bodily fluids, and the studies designed to test for changes in adenosine levels have been seriously flawed. In one study patients were given a dose of methotrexate and then immediately had blood and rectal fluid collected for measurement of adenosine, ${ }^{31}$ a design at odds with the long latent period required for the accumulation of the long lived methotrexate metabolites that mediate the adenosine release. Similarly, in another study patients were studied 1 week after receiving a single dose of methotrexate when, again, accumulation of long term metabolites and therapeutic response would not have been expected to have occurred..$^{32}$

\section{EVIDENCE FOR THE EFFECT OF METHOTREXATE TREATMENT IN RA}

Thus, in the paper by Riksen and colleagues published in this issue the authors provide some of the first evidence that methotrexate treatment for RA leads to altered adenosine kinetics in patients. $^{33}$ Adenosine, acting at its receptors in the vasculature, has long been known to be a potent vasodilator Thus these authors examined forearm blood flow (FBF) responses to adenosine before and after 12 weeks of methotrexate treatment as a surrogate for methotrexate mediated alterations in adenosine metabolism. They found that adenosine increased FBF much more in the patients after methotrexate treatment. Moreover, when they infused dipyridamole into the patients (which prevents adenosine uptake) they found a clear increase in FBF after methotrexate treatment. The authors noted that adenosine deaminase levels were significantly lower in lymphocytes after methotrexate treatment and suggested that this might account for the change in FBF responses. However, it is difficult to understand how a $25 \%$ decrease in adenosine deaminase activity in lymphocytes (but not erythrocytes) could significantly affect adenosine metabolism because most of the adenosine deaminase activity in blood is in the erythrocytes.

Another jarring note in this study is that although all the patients appeared to respond to methotrexate with altered adenosine kinetics, their arthritis did not respond to the drug, suggesting that either the joint tissue was unaffected or that methotrexate mediated alterations in adenosine levels may be necessary, but not sufficient, to suppress inflammatory arthritis. None the less, this work clearly demonstrates, using a surrogate marker, that methotrexate treatment modulates adenosine metabolism in patients with RA and provides further support for the hypothesis that increased extracellular adenosine mediates the anti-inflammatory effects of methotrexate.

Ann Rheum Dis 2006;65:421-422.

doi: 10.1136/ard.2005.049601

Correspondence to: Professor B N Cronstein, Department of Medicine, Pathology, and Pharmacology, NYU School of Medicine, 550 First Ave, New York, NY 10016, USA: Cronsb01@med.nyu.edu

Accepted 7 January 2006

\section{REFERENCES}

Weinblatt ME, Coblyn JS, Fox DA, Fraser PA, Holdsworth DE, Glass DN, et al. Efficacy of lowdose methotrexate in rheumatoid arthritis. N Engl J Medicine 1985;312:818-22.

2 Williams HJ, Wilkens RF, Samuelson CO Jr, Alarcon GS, Guttadauria M, Yarboro C, et al. Comparison of low-dose oral pulse methotrexate and placebo in the treatment of rheumatoid arthritis: a controlled clinical trial. Arthritis Rheum 1985;28:721-30

3 Bathon JM, Martin RW, Fleischmann RM, Tesser JR, Schiff MH, Keystone EC, et al. A comparison of etanercept and methotrexate in patients with early rheumatoid arthritis. N Engl J Med 2000;343:1586-93.

4 Genovese MC, Bathon JM, Martin RW Fleischmann RM, Tesser JR, Schiff MH, et al. Etanercept versus methotrexate in patients with early rheumatoid arthritis. Two-year radiographic and clinical outcomes. Arthritis Rheum 2002;46:1443-50.

5 Bathon JM, Genovese MC. The Early Rheumatoid Arthritis (ERA) trial comparing the efficacy and safety of etanercept and methotrexate. Clin Exp Rheumatol 2003;21(suppl 31):S195-7.

6 Klareskog L, van der Heijde D, de Jager JP, Gough A, Kalden J, Malaise M, et al. Therapeutic 
effect of the combination of etanercept and methotrexate compared with each treatment alone in patients with rheumatoid arthritis: double-blind randomised controlled trial. Lancet 2004;363:675-81.

7 Edwards JC, Szczepanski L, Szechinski J, Filipowicz-Sosnowska A, Emery P, Close DR, et al. Efficacy of B-cell-targeted therapy with rituximab in patients with rheumatoid arthritis. N Engl J Med 2004;350:2572-81.

8 Morgan SL, Oster RA, Lee JY, Alarcon GS, Baggott JE. The effect of folic acid and folinic acid supplements on purine metabolism in methotrexate-treated rheumatoid arthritis. Arthritis Rheum 2004;50:3104-11.

9 Nesher G, Moore TL. The in vitro effects of methotrexate on peripheral blood mononuclear cells. Modulation by methyl donors and spermidine. Arthritis Rheum 1990;33:954-9.

10 Nesher G, Moore TL, Dorner RW. In vitro effects of methotrexate on peripheral blood monocytes: modulation by folinic acid and $\mathrm{S}$ adenosylmethionine. Ann Rheum Dis 1991;50:637-41.

11 Nesher G, Osborn TG, Moore TL. In vitro effects of methotrexate on polyamine levels in lymphocytes from rheumatoid arthritis patients. Clin Exp Rheumatol 1996; 14:395-9.

12 Cronstein BN, Eberle MA, Gruber HE, Levin RI. Methotrexate inhibits neutrophil function by stimulating adenosine release from connective tissue cells. Proc Natl Acad Sci USA 1991;88:2441-5.

13 Asako H, Wolf RE, Granger DN. Leukocyte adherence in rat mesenteric venules: effects of adenosine and methotrexate. Gastroenterology 1993; 104:31-7.

14 Cronstein BN, Naime D, Ostad E. The antiinflammatory mechanism of methotrexate: increased adenosine release at inflamed sites diminishes leukocyłe accumulation in an in vivo model of inflammation. J Clin Invest 1993;92:2675-82.

15 Cronstein BN. Low-dose methotrexate: a mainstay in the treatment of rheumatoid arthritis Pharmacol Rev 2005;57:163-72.
16 Morgan SL, Baggott JE, Vaughn WH, Young PK Austin JV, Krumdieck CL, et al. The effect of folic acid supplementation on the toxicity of low-dose methotrexate in patients with rheumatoid arthritis. Arthritis Rheum 1990;33:9-18.

17 Morgan SL, Baggott JE, Refsum H, Ueland PM. Homocysteine levels in patients with rheumatoid arthritis treated with low-dose methotrexate. Clin Pharmacol Ther 1991;50(Pt 1):547-56.

18 Morgan SL, Baggott JE, Vaughn WH, Austin JS, Veitch TA, Lee JY, et al. Supplementation with folic acid during methotrexate therapy for rheumatoid arthritis. A double-blind, placebocontrolled trial. Ann Intern Med

1994;121:833-41.

19 van Ede AE, Laan RF, Rood MJ, Huizinga TW, van de Laar MA, van Denderen CJ, et al. Effect of folic or folinic acid supplementation on the toxicity and efficacy of methotrexate in rheumatoid arthritis: a forty-eight week, multicenter, randomized, double-blind, placebo-controlled study. Arthritis Rheum 2001;44:1515-24.

20 Ortiz Z, Shea B, Suarez Almazor M, Moher D Wells $G$, Tugwell P. Folic acid and folinic acid for reducing side effects in patients receiving methotrexate for rheumatoid arthritis. Cochrane Database Syst Rev 2000;2:CD000591.

21 Ortiz Z, Shea B, Suarez-Almazor ME, Moher D Wells GA, Tugwell P. The efficacy of folic acid and folinic acid in reducing methotrexate gastrointestinal toxicity in rheumatoid arthritis. A metaanalysis of randomized controlled trials. J Rheumatol 1998;25:36-43.

22 Hunt PG, Rose CD, Mcllvain-Simpson G, Tejani S The effects of daily intake of folic acid on the efficacy of methotrexate therapy in children with juvenile rheumatoid arthritis. A controlled study. $J$ Rheumatol 1997;24:2230-2.

23 Morgan SL, Baggott JE, Lee JY, Alarcon GS. Folic acid supplementation prevents deficient blood folate levels and hyperhomocysteinemia during longterm, low dose methotrexate therapy for rheumatoid arthritis: implications for cardiovascular disease prevention. J Rheumatol 1998;25:441-6.
24 Shiroky JB, Neville C, Esdaile JM, Choquette D, Zummer M, Hazeltine, et al. Low-dose methotrexate with leucovorin (folinic acid) in the management of rheumatoid arthritis. Results of a multicenter randomized, double-blind, placebocontrolled trial. Arthritis Rheum 1993;36:795-803.

25 Buckley LM, Vacek PM, Cooper SM Administration of folinic acid after low dose methotrexate in patients with rheumatoid arthritis. J Rheumatol 1990;17:1158-61.

26 Smith DM, Johnson JA, Turner RA. Biochemical perturbations of BW 91Y (3-deazaadenosine) on human neutrophil chemotactic potential and lipid metabolism. Int J Tissue React 1991;13:1-18.

27 Silke C, Murphy MS, Buckley T, Busteed S, Molloy MG, Phelan M. The effects of caffeine ingestion on the efficacy of methotrexate [abstract]. Rheumatology (Oxford) 2001;40(suppl 1):34.

28 Nesher G, Mates M, Zevin S. Effect of caffeine consumption on efficacy of methotrexate in rheumatoid arthritis. Arthritis Rheum 2003;48:571-2.

29 Ralph JA, McEvoy AN, Kane D, Bresnihan B, Fitzgerald O, Murphy EP. Modulation of Orphan nuclear receptor NURRI expression by methotrexate in human inflammatory joint disease involves adenosine $\mathrm{A} 2 \mathrm{~A}$ receptor-mediated responses. J Immunol 2005; 175:555-65.

30 Moser GH, Schrader JH, Deussen A. Turnover of adenosine of human and dog blood. Am J Physiol 1989;256:C799-806.

31 Egan LJ, Sandborn WJ, Mays DC, Tremaine WJ, Lipsky JJ. Plasma and rectal adenosine in inflammatory bowel disease: effect of methotrexate. Inflamm Bowel Dis 1999:5: 167-73.

32 Smolenska Z, Kaznowska Z, Zarowny D, Simmonds HA, Smolenski RT. Effect of methotrexate on blood purine and pyrimidine levels in patients with rheumatoid arthritis. Rheumatology (Oxford) 1999;38:997-1002.

33 Riksen NP, Barrera P, van den Broek PHH, van Riel PLCM, Smits P, Rongen GA. Methotrexate modulates the kinetics of adenosine in humans in vivo. Ann Rheum Dis 2006;65:465-70. 